\title{
Intercellular Calcium Waves in Cultured Enteric Glia From Neonatal Guinea Pig
}

\author{
WEIZHEN ZHANG, BRADLEY J. SEGURA, THEODORE R. LIN, YUEXIAN HU, \\ AND MICHAEL W. MULHOLLAND* \\ Michigan Gastrointestinal Peptide Center, Department of Surgery, \\ University of Michigan, Ann Arbor, Michigan
}

KEYWORDS enteric nervous system; intercellular signaling; calcium dynamics; $\mathrm{IP}_{3}$; gap junction

\begin{abstract}
Enteric glia are important participants in information processing in the enteric nervous system. However, intercellular signaling mechanisms in enteric glia remain largely unknown. We postulated that intercellular calcium waves exist in enteric glia. Primary cultures of enteric glia were isolated from neonatal guinea pig taenia coli. Intracellular calcium in individual cells was quantified with fura-2 AM microfluorimetry. Single-cell stimulation was performed with a micromanipulator-driven glass pipette. Data were expressed as mean \pm SEM and analyzed by Student's $t$-test. Mechanical stimulation of a single enteric glial cell resulted in an increase in intracellular calcium, followed by concentric propagation to $36 \% \pm 3 \%$ of neighboring cells. Intercellular calcium waves were blocked by depletion of intracellular calcium stores with thapsigargin $(1 \mu \mathrm{M})$. Pretreatment of enteric glia with the phospholipase $\mathrm{C}$ inhibitor U73122 $(1 \mu \mathrm{M})$ significantly decreased the percentage of cells responding to mechanical stimulation $(6 \% \pm 4 \%)$, but had no effect on waves induced by microinjection of the inositol trisphosphate $(67 \% \pm 13 \%$ vs. $60 \% \pm 4 \%$ for control). Antagonism of inositol trisphosphate receptor attenuated intercellular calcium waves induced by both mechanical stimulation and microinjection of inositol trisphosphate. Uncoupling of gap junctions with octanol or heptanol significantly inhibited intercellular calcium wave propagation. Pretreatment of enteric glia with apyrase partially attenuated intercellular calcium waves. Our data demonstrate that enteric glial cells are capable of transmitting increases in intracellular calcium to surrounding cells, and that intercellular calcium waves involve a sequence of intracellular and extracellular steps in which phospholipase C, inositol trisphosphate, and ATP play roles. GLIA 42:252-262, 2003.
\end{abstract}

๑ 2003 Wiley-Liss, Inc.

\section{INTRODUCTION}

The enteric nervous system (ENS), located in the wall of the gastrointestinal tract, is the largest division of the peripheral nervous system. The ENS is recognized as an independent integrative system, which participates in virtually all aspects of gastrointestinal function, including motility, secretion, absorption, and regulation of blood flow. Two major cell types comprise the ENS: neurons and glia. Enteric glia represent the most abundant cells in the enteric nervous system. The traditional assumption that enteric glia serve only as supportive or nutritive elements for enteric neurons is currently being challenged.
Although enteric glia have an essential role in the ENS, little is known about molecular signaling mechanisms in enteric glia. Studies using dissociated enteric glia have utilized a convenient model and have yielded important information regarding intracellular calcium signaling events. A variety of neurotransmit-

\footnotetext{
Grant sponsor: the National Institutes of Health; Grant number: DK43225.

*Correspondence to: Dr. Michael W. Mulholland, 2101 Taubman, 1500 E. Medical Center Drive, Ann Arbor, MI 48109. E-mail: micham@umich.edu

Received 28 August 2002; Accepted 13 January 2003

DOI 10.1002/glia.10215
} 
ters and other extracellular signaling molecules have been reported to induce intracellular calcium signaling in single enteric glia (Kimball and Mulholland, 1996; Zhang et al., 1997). However, intercellular signaling mechanisms in collections of synchronized enteric glia remain largely unknown. In many tissues, the functional unit of the organ is not a single cell but collections of cells connected by membrane-spanning gap junctions. Intercellular propagation of calcium waves has been described in a wide variety of cell types and is considered one of the main mechanisms by which cooperative cell activity is coordinated (Boitano et al., 1992; Charles et al., 1993; Yule et al., 1996; Venance et al., 1997; Churchill and Louis, 1998; Scemes et al., 2000; Hirata et al., 2002).

Propagation of calcium waves can be mediated by intracellular or extracellular diffusion of messenger molecules. Signaling molecules such as inositol trisphosphate $\left(\mathrm{IP}_{3}\right)$, calcium, and cyclic $\mathrm{ADP}$ ribose have been shown to pass from the cytosol of one cell to another via gap junctions (Boitano et al., 1992; Yule et al., 1996; Churchill and Louis, 1998). Alternatively, ATP and glutamate are extracellular messengers that may cause calcium signals in neighboring cells that may or may not be in direct contact (Guthrie et al., 1999; Scemes et al., 2000). In the enteric nervous system, glia-to-glia dye coupling has been reported (Hanani et al., 1989), suggesting the existence of an enteric glial network. We postulated that intercellular calcium waves are a communication feature of glial cells in the enteric nervous system.

In the present study, we demonstrate that mechanical stimulation results in increases in intracellular calcium concentration $\left(\left[\mathrm{Ca}^{2+}\right]_{\mathrm{i}}\right)$ in individual cells of cultured enteric glia, and that these increases travel in a wavelike fashion between adjoining neighboring cells. Propagation of intercellular calcium waves in enteric glia involves a sequence of intracellular steps in which phospholipase $\mathrm{C}$ and $\mathrm{IP}_{3}$ play critical roles and occurs through both gap junctional communication and release of extracellular ATP.

\section{MATERIALS AND METHODS}

Fura-2 acetoxymethyl ester (fura-2 AM) and fura-2 free acid were from Molecular Probes (Eugene, OR). U73122, ATP, $\mathrm{IP}_{3}$, thapsigargin, octanol, heptanol, apyrase, collagenase type IV, trypsin-EDTA, trypsin inhibitor, penicillin-streptomycin solution, HEPES, and Lucifer Yellow were purchased from Sigma Chemical (St. Louis, MO). 2-aminoethoxydiphenyl borate (2APB) was from Tocris (Ballwin, MO). Hank's balanced salt solution, medium 199, and L-glutamine were from Gibco-BRL (Grand Island, NY). NU-serum I was from Collaborative Research (Bedford, MA). Neonatal male Duncan-Hartley guinea pigs were obtained from Simonsen Labs (Gilroy, CA).

\section{Cultures of Enteric Glia}

Dispersed primary cultures of guinea pig enteric glia were prepared on collagen-coated coverslips and used for experiments within 5 days. The taenia coli from 1-day-old male Duncan-Hartley guinea pigs were removed and placed in Hanks balanced saline solution plus $0.1 \%$ collagenase (type IV) for $16-20 \mathrm{~h}$ at $4^{\circ} \mathrm{C}$. After 35 -min incubation at $37^{\circ} \mathrm{C}$, the myenteric plexus of the taenia coli was separated from the muscle layers using a dissecting microscope. The plexus was incubated for $30 \mathrm{~min}$ at $37^{\circ} \mathrm{C}$ using trypsin-EDTA $(0.5 \mathrm{~g} / \mathrm{L}$ trypsin, 0.5 mM EDTA) solution, triturated with siliconized flamed Pasteur pipettes of decreasing tip diameter, and plated on collagen-coated coverslips. Cultures were maintained in medium 199 supplemented with $5 \% \mathrm{NU}$-serum I, $1 \mathrm{mM}$ sodium-pyruvate, $5 \mathrm{mg} / \mathrm{ml}$ glucose, $0.2 \mathrm{mM}$ L-glutamine, and $0.001 \%$ trypsin inhibitor (type I-S from soybean). Penicillin-streptomycin solution was added for the first $48 \mathrm{~h}$ at a $2 \%$ concentration. Antimitotic agents were not added. Media were changed every other day. The cultures were incubated at $37^{\circ} \mathrm{C}$ with $5 \% \mathrm{CO}_{2}$.

\section{Loading and Cell Preparation for Imaging}

Cultured enteric glia were incubated at $37^{\circ} \mathrm{C}$ in fresh warmed media containing $0.5 \mu \mathrm{M}$ fura-2 AM for 45 min. Loaded coverslips were washed, resuspended in control calcium buffer $(\mathrm{pH} 7.40$, containing in $\mathrm{mM}$, $\mathrm{NaCl} 118, \mathrm{KCl} 4.7, \mathrm{CaCl}_{2}$ 1.8, $\mathrm{HEPES} 10, \mathrm{NaHCO}_{3} 15$, glucose $11, \mathrm{NaH}_{2} \mathrm{PO}_{4} 0.9, \mathrm{MgSO}_{4} 0.8$ ), and placed in a perfusion chamber. The superfusion rate of the control buffer and experimental solution was $1 \mathrm{ml} / \mathrm{min}$. For calcium-free conditions, $\mathrm{CaCl}_{2}$ was removed from the buffer and $1 \mathrm{mM}$ EGTA added. For experiments conducted under calcium-free conditions, cells were loaded and maintained in calcium-containing buffer until just prior to initiation of intracellular calcium measurements.

\section{Calcium Measurements}

A Zeiss Axiovert inverted microscope and Attofluor digital imaging system (Rockville, MD) were used for single-cell $\left[\mathrm{Ca}^{2+}\right]_{\mathrm{i}}$ determinations. $\left[\mathrm{Ca}^{2+}\right]_{\mathrm{i}}$ was calculated from the ratios of the $540 \mathrm{nM}$ emission fluorescence intensities of fura-2 AM when stimulated at 334 and $380 \mathrm{nM}$. Calibration of the system was performed with the two-point standardization equation using fura-2 free acid: $\left[\mathrm{Ca}^{2+}\right]_{\mathrm{i}}=\mathrm{K}_{\mathrm{d}}\left[\left(\mathrm{R}-\mathrm{R}_{\mathrm{Lo}}\right) /\left(\mathrm{R}_{\mathrm{Hi}}-\mathrm{R}\right)\right] \mathrm{b}$, where $\mathrm{K}_{\mathrm{d}}$ is the dissociation constant of the $\mathrm{Ca}^{2+} /$ fura-2 AM complex ( $225 \mathrm{nM}), \mathrm{R}$ is $\mathrm{F}_{334} / \mathrm{F}_{380}$, i.e., the fluorescence at $334 \mathrm{~nm}$ excitation divided by the fluorescence at $380 \mathrm{~nm}$ excitation, $R_{\mathrm{Lo}}$ is the ratio at zero calcium (1 mM EGTA), $R_{\mathrm{Hi}}$ is the ratio at high calcium ( $1 \mathrm{mM}$ $\mathrm{CaCl}_{2}$ ), and $\mathrm{b}$ is $\mathrm{F}_{380}\left(\right.$ zero $\left.\mathrm{Ca}^{2+}\right) / \mathrm{F}_{380}$ (saturating $\mathrm{Ca}^{2+}$ ). A ratio pair was measured every $1.5 \mathrm{~s}$. 

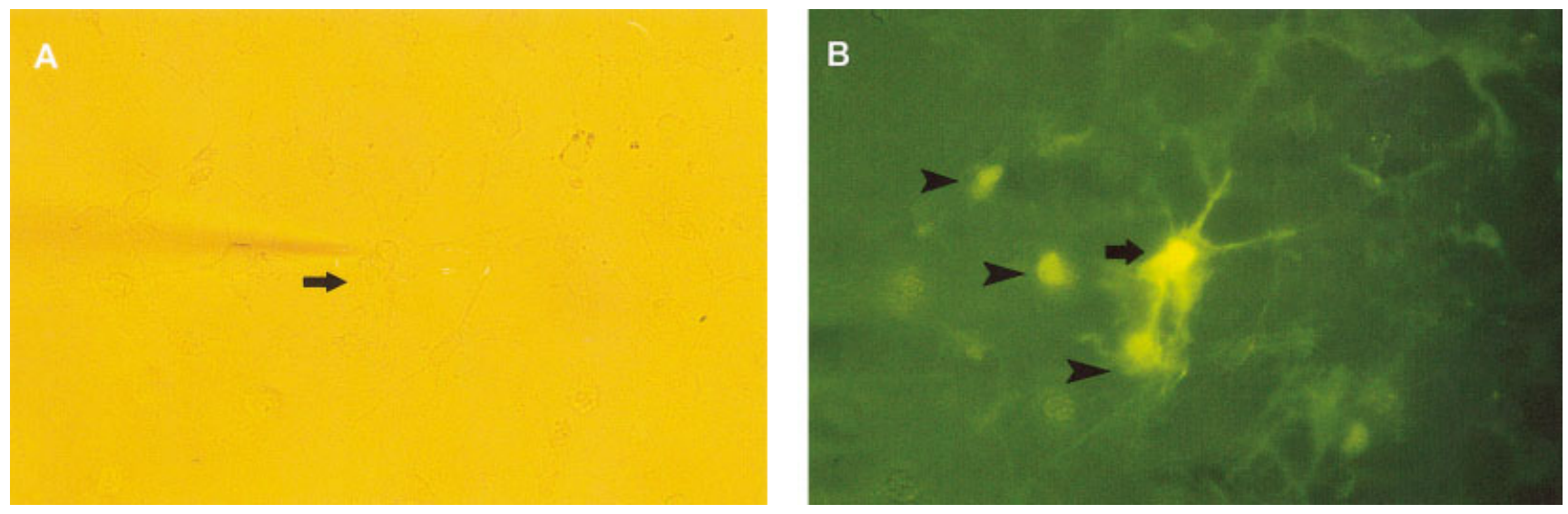

Fig. 1. Dye coupling of enteric glia. A single enteric glia was injected with $4 \%$ Lucifer Yellow and viewed with fluorescence microscope. Arrow indicates the cell injected (A). Dye spreading was observed in neighboring cells (arrowheads; B).

\section{Cell Stimulation}

Mechanical stimulation was performed with a patchclamp pipette driven by a pneumatic micromanipulator (Burleigh, Rochester, NY) to touch gently the surface of an enteric glia. After mechanical stimulation, $\left[\mathrm{Ca}^{2+}\right]_{\mathrm{i}}$ was measured for up to $5 \mathrm{~min}$. In separate experiments, microinjection of messenger molecules and indicator dye was performed using the same pneumatic micromanipulator mounted on the stage of an Axiovert 35 microscope/Attofluor imaging system, which was positioned on a vibration isolation platform. Patchclamp pipettes were filled with test agents together with $4 \%$ Lucifer Yellow in a buffer solution containing $120 \mathrm{mM}$ potassium glutamate and $20 \mathrm{mM}$ HEPES adjusted to $\mathrm{pH}$ 7.2. The pipette solution was filtered through a $0.22 \mu \mathrm{m}$ filter. The approach and penetration of a single enteric glia were accomplished by making multiple $2 \mu \mathrm{m}$ jumps toward the cell. After penetration and pressure application, the pipette was rapidly withdrawn by making a single reverse jump of $15 \mu \mathrm{m}$. The success of the injection was assessed by monitoring the morphology of the cell before and after injection, together with the ability of the cell to retain the injected indicator and previously loaded fluorescent dye. Experiments were rejected when the cell membrane was damaged as revealed by a leak of fluorescent probe from the cell. Focal application of drugs was performed by applying a pressure pulse (30 psi, $20 \mathrm{~ms})$ with a pneumatic pico pump (PV830, World Precision Instruments) connected to a patch-clamp pipette filled with the calcium buffer containing the tested compound. The patch-clamp pipette was positioned to about 20-40 $\mu \mathrm{m}$ from the targeted cell. The control for the focal application of drugs was achieved by using the calcium buffer alone.

\section{Data Presentation and Calculation}

Results are presented as mean \pm SEM. Data were analyzed using ANOVA. Significance was accepted as
$P<0.05$. In this study, n equals the number of experiments. An enteric glia was judged to have responded to stimulation if its $\left[\mathrm{Ca}^{2+}\right]_{\mathrm{i}}$ increased by at least $50 \mathrm{nM}$ over baseline. Results have been calculated only from those responding glia having basal $\left[\mathrm{Ca}^{2+}\right]_{\mathrm{i}}$ level of $<$ $150 \mathrm{nM}$, a criterion met by over $95 \%$ of glia. Glia with high intracellular calcium prior to any stimulation were considered damaged or leaky and were excluded from study. There was only one microscope field examined per coverslip. Peak intracellular calcium was measured as the highest $\left[\mathrm{Ca}^{2+}\right]_{\mathrm{i}}$ concentration achieved during stimulation.

At least four coverslips of cultured enteric glia were used for each experimental condition. Each experimental condition was tested on glia from at least three separate preparations of a total of six animals. Dissection techniques, tissue preparation, media, and reagent vendors remained constant throughout the study.

Enteric glia were distinguished from neurons using two criteria. First, morphology. Enteric glia 5-7 days postplating are flat with many cytoplasmic processes. They are less phase-bright than neurons. Enteric glia also have a larger, more dense nucleus with wide surrounding cytoplasm. Cells with this morphology stain positively for glial fibrillary acid protein (GFAP), a glial marker. Second, KCL depolarization. At the end of each experiment, the coverslip was superfused with 55 $\mathrm{mM} \mathrm{KCl}$. This exposure only depolarized myenteric neurons, increasing intracellular calcium. Enteric glia demonstrated no significant response in intracellular calcium signaling to depolarization.

\section{RESULTS}

\section{Dye Coupling in Enteric Glia}

Intracellular injection of Lucifer Yellow revealed a distinct morphology of enteric glial cells. As shown in Figure 1, the cell body of enteric glia was small and 

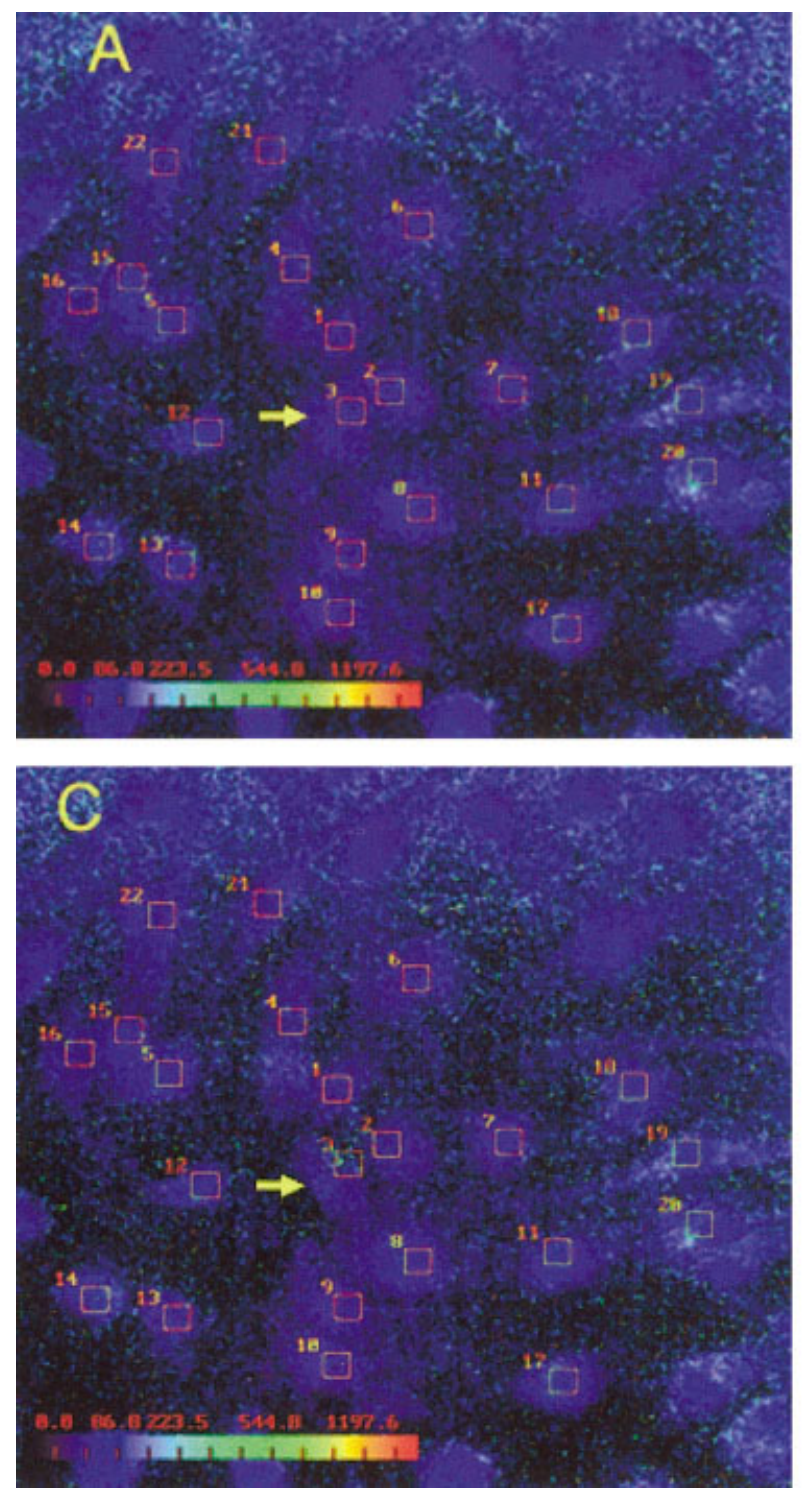

Fig. 2. Intercellular calcium waves in mechanically stimulated enteric glia. A: Cells before stimulation had basal $\left[\mathrm{Ca}^{2+}\right]_{\mathrm{i}}$ of $36 \pm 3 \mathrm{nM}$ as represented by the pseudocolor blue. Arrow indicates the cell being stimulated. B: Image taken $2 \mathrm{~s}$ after stimulation. Increase of $\left[\mathrm{Ca}^{2+}\right]_{i}$ was propagated from the stimulated cell to neighboring cells as rep-

processes were short and fine. The fluorescence intensity was highest in the cell body region. When a single cell was injected with Lucifer Yellow, dye coupling was observed in $18 \pm 6$ neighboring cells.

\section{Calcium Waves in Enteric Glia}

Basal $\left[\mathrm{Ca}^{2+}\right]_{\mathrm{i}}$ in resting cultured enteric glia was $36 \pm 3 \mathrm{nM}(\mathrm{n}=1,198$ cells $)$. The average number of cells present in the microscopic field was $32 \pm 5(62$ separate experiments). Single-cell stimulation was performed either by mechanical stimulation with a micromanipulator-driven patch-clamp pipette or by
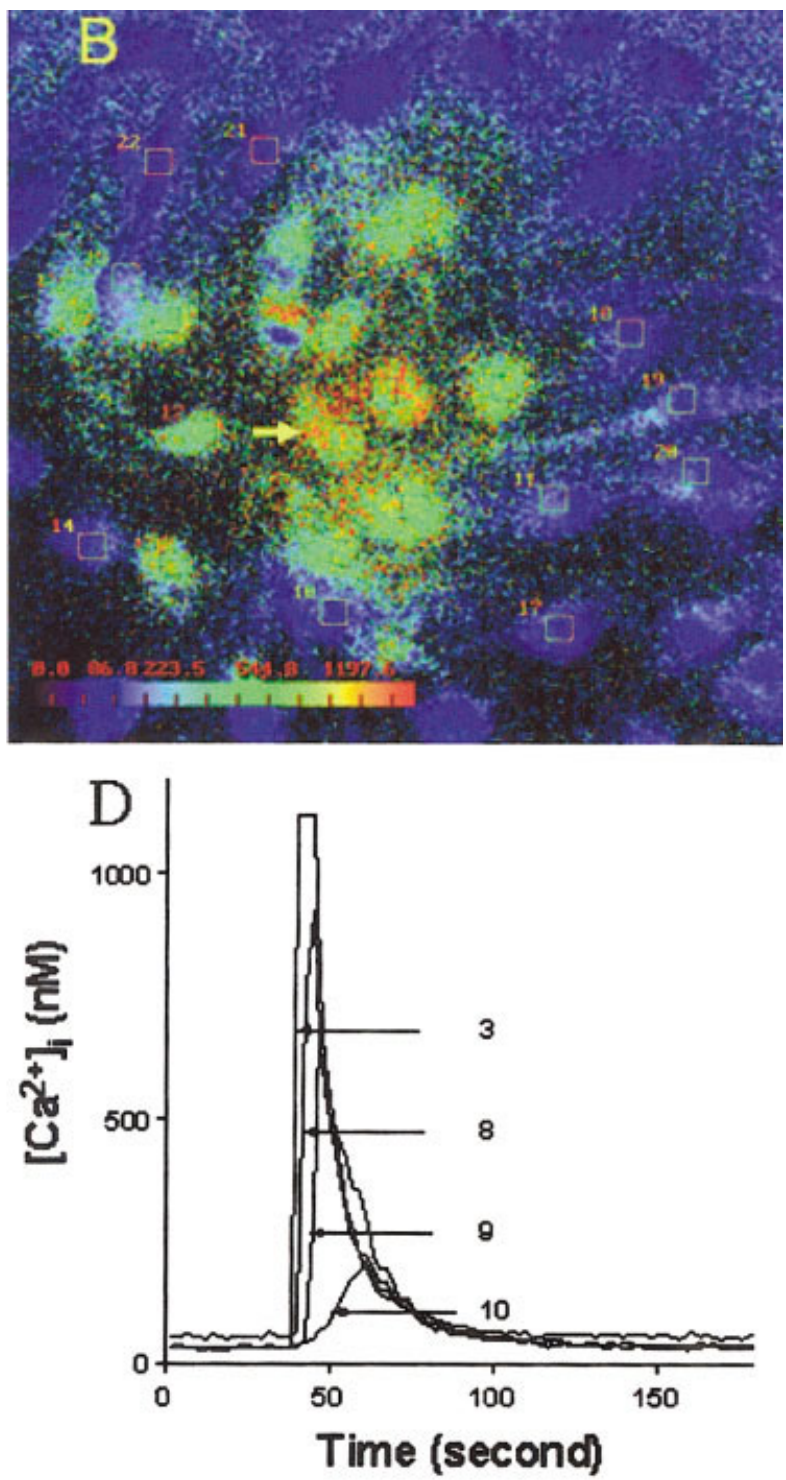

resented by the change of pseudocolor. C: Image taken 2 min after stimulation. $\left[\mathrm{Ca}^{2+}\right]$ in all cells returned to basal level. D: Individual tracings of $\left[\mathrm{Ca}^{2+}\right]_{\mathrm{i}}$ in selected cells. Note the increasing lag period and decreasing magnitude of the $\left[\mathrm{Ca}^{2+}\right]_{\mathrm{i}}$ response with increasing distance from the originally stimulated cell (cell 3 ). close proximity pressure application from a patchclamp pipette filled with $100 \mu \mathrm{M}$ ATP or $1 \mu \mathrm{M}$ endothelin 3.

Mechanical stimulation of a single enteric glia always evoked increases in $\left[\mathrm{Ca}^{2+}\right]_{\mathrm{i}}$ in the stimulated cell. The mean $\left[\mathrm{Ca}^{2+}\right]_{\mathrm{i}}$ increment induced by mechanical stimulation was $432 \pm 14 \mathrm{nM}(\mathrm{n}=62)$. The $\left[\mathrm{Ca}^{2+}\right]_{\mathrm{i}}$ responses were rapidly reversed; $\left[\mathrm{Ca}^{2+}\right]_{\mathrm{i}}$ returned to initial values within 2 min in $81 \% \pm 5 \%$ of trials performed with mechanical stimulation. An increment in $\left[\mathrm{Ca}^{2+}\right]_{\mathrm{i}}$ propagated outward from the site of stimulation to surrounding enteric glia. Mechanical stimulation of a single cell in cultured enteric glia resulted in an increase in $\left[\mathrm{Ca}^{2+}\right]_{\mathrm{i}}$ in $36 \% \pm 3 \%$ of cells present in 


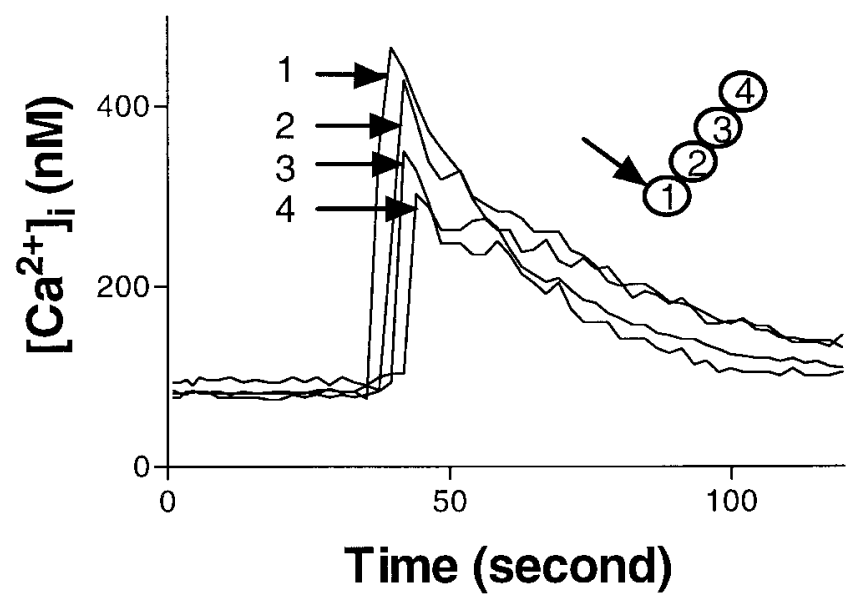

Fig. 3. Intercellular calcium waves in chemically stimulated enteric glia. Each numbered tracing corresponds to the numbered cell in the inset diagram. Focal application of ATP $(100 \mu \mathrm{M})$ to cell 1 induced an increase of $\left[\mathrm{Ca}^{2+}\right]_{\mathrm{i}}$, which was rapidly propagated to the neighboring cells. $n=5$.

the microscopic field. Figure 2 shows a typical intercellular calcium wave induced by mechanical stimulation in enteric glia.

Close proximity application of ATP or endothelin elicited mean $\left[\mathrm{Ca}^{2+}\right]_{\mathrm{i}}$ increments of $209 \pm 50 \mathrm{nM}(\mathrm{n}=$ 4) and $310 \pm 60 \mathrm{nM}(\mathrm{n}=5)$, respectively. ATP or endothelin focal application induced a widespread propagation of intercellular calcium waves in enteric glia, which extended beyond the microscopic field being examined. Figure 3 shows the typical tracing of $\left[\mathrm{Ca}^{2+}\right]_{i}$ increase in a wavelike form following the focal application of ATP to cell 1.

\section{Role of External Calcium}

To study the mechanisms of wave propagation, mechanical stimulation was used in the following experiments. In calcium-free buffer, mechanical stimulation induced intercellular calcium increments in 33\% $\pm 5 \%$ of enteric glia, similar to responses observed in the presence of extracellular $\mathrm{Ca}^{2+}$ (Fig. 4). Thus, propagation of $\mathrm{Ca}^{2+}$ waves after mechanical stimulation does not depend on extracellular calcium. To determine whether initiation and propagation of $\mathrm{Ca}^{2+}$ waves are mediated by release of calcium from intracellular stores, we applied the endoplasmic reticulum $\mathrm{Ca}^{2+}$. ATPase inhibitor thapsigargin $(1 \mu \mathrm{M})$ in a $\mathrm{Ca}^{2+}$-free extracellular solution to deplete intracellular calcium stores. After thapsigargin administration, mechanical stimulation did not produce a change in $\left[\mathrm{Ca}^{2+}\right]_{i}$ in either stimulated or neighboring cells (Fig. 4), indicating that mechanically stimulated $\mathrm{Ca}^{2+}$ waves are mediated by releasing $\mathrm{Ca}^{2+}$ from intracellular stores rather than $\mathrm{Ca}^{2+}$ influx from extracellular stores.

\section{Role of Phospholipase $\mathrm{C}$ and $\mathrm{IP}_{3}$}

Activation of phospholipase $\mathrm{C}$ and $\mathrm{IP}_{3}$ receptors has been reported to be involved in intercellular calcium waves in respiratory epithelial cells (Boitano et al., 1992), hepatocytes (Hirata et al., 2002), pancreatic acinar cells (Yule et al., 1996), and astrocytes (Venance et al., 1997). It is possible that a calcium-dependent activation of phospholipase C (PLC) could participate in the initiation and propagation of intercellular calcium waves in enteric glia. To test this possibility, the amino steroid U73122 (a specific PLC inhibitor) was used. Previous work from our laboratory (Zhang et al., 1997) has demonstrated that increments in $\left[\mathrm{Ca}^{2+}\right]_{\mathrm{i}}$ induced by endothelin, a potent activator of PLC, is blocked by U73122. As shown in Figure 5, pretreatment of cultured enteric glia with $1 \mu \mathrm{M}$ U73122 significantly decreased the percentage of cells responding to mechanical stimulation.

Because $\mathrm{IP}_{3}$ production results from activation of PLC, we next tested if microinjection of $\mathrm{IP}_{3}$ could initiate intercellular calcium waves in enteric glia. Enteric glia were impaled, then allowed to recover from mechanical stimulation before microinjection of $\mathrm{IP}_{3}$. As shown in Figure 6, intracellular microinjection of 100 $\mu \mathrm{M} \mathrm{IP}{ }_{3}$ caused an increment of $\left[\mathrm{Ca}^{2+}\right]_{\mathrm{i}}$ in the targeted cells $\left(\Delta\left[\mathrm{Ca}^{2+}\right]_{\mathrm{i}}=419 \pm 36 \mathrm{nM}, \mathrm{n}=11\right.$ cells $)$, followed by propagation of calcium waves to $60 \% \pm 4 \%$ of cells in the microscopic field. These results demonstrate that microinjection of $\mathrm{IP}_{3}$ is effective in initiating intercellular calcium waves in enteric glia. As shown in Figure 6 , pretreatment of enteric glia with $1 \mu \mathrm{M}$ U73122 did not alter the generation of intercellular calcium waves by $\mathrm{IP}_{3}$.

The role of $\mathrm{IP}_{3}$ in intercellular calcium waves in enteric glia was further investigated using the membrane-permeable $\mathrm{IP}_{3}$ receptor antagonist 2-aminoethoxydiphenyl borate (2APB) (Ma et al., 2000). 2APB has been utilized in a variety of cell types to reversibly modulate $\mathrm{IP}_{3}$ receptor activity, including enteric glia. In this investigation, basal $\left[\mathrm{Ca}^{2+}\right]_{\mathrm{i}}$ was not affected by $2 \mathrm{APB}$ at the concentration used. Following pretreatment of enteric glia with $100 \mu \mathrm{M} 2 \mathrm{APB}$, no propagation of intercellular calcium waves was observed in enteric glia activated by either mechanical stimulation or by microinjection of $\mathrm{IP}_{3}$ (Fig. 7).

\section{Participation of Gap Junctions in Propagation of Intercellular Calcium Waves}

Gap junctions constitute a direct intercytoplasmic pathway that allows the exchange of ions and small molecules, including calcium and $\mathrm{IP}_{3}$. Using Lucifer Yellow, a low-molecular-weight hydrophilic fluorescent dye that has been used as a qualitative marker for gap junctional communication, we detected dye transfer in direct neighbors immediately after injection, indicating the existence of gap junctions in enteric glia. To demonstrate the requirement for functional gap junctions 
A
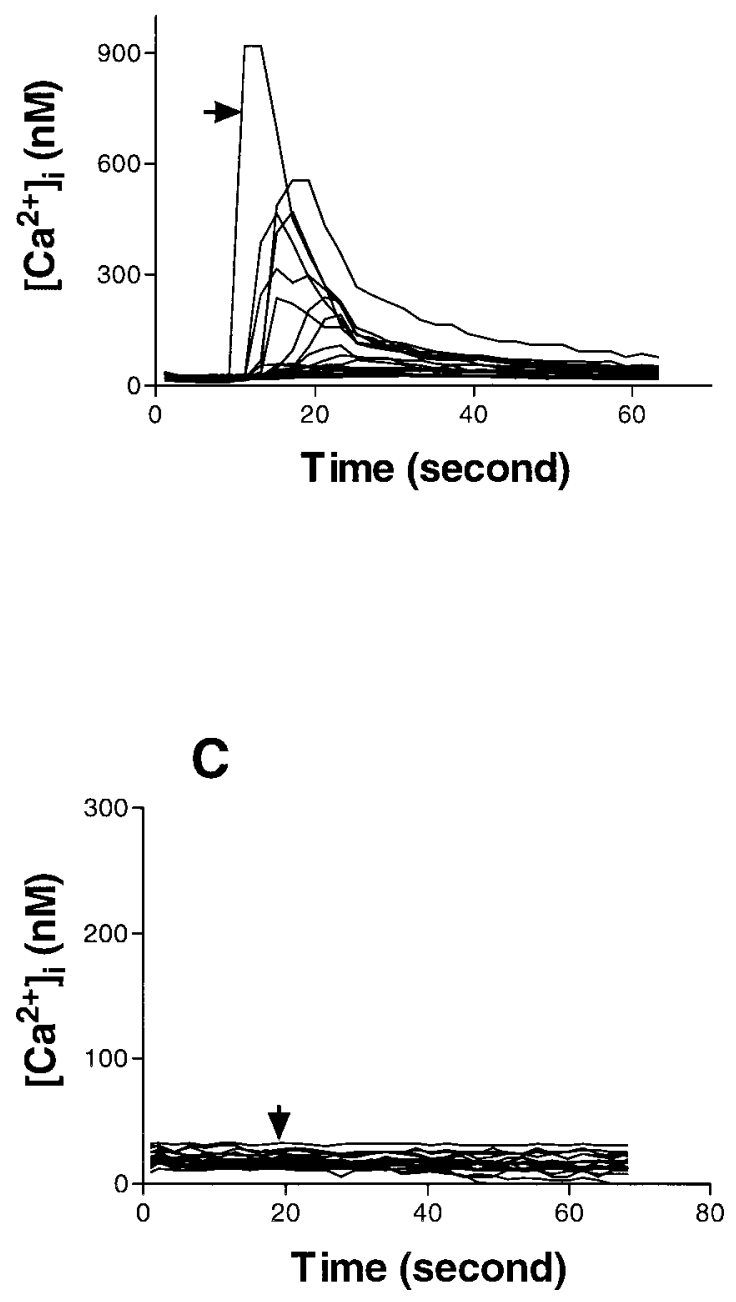

Fig. 4. Absence of intercellular calcium waves in enteric glia with depletion of internal calcium stores. A: Propagation of mechanically induced calcium waves was observed in control cells. B: Removal of extracellular calcium demonstrated no effect on calcium waves induced by mechanical stimulation. C: Depletion of internal calcium stores with $1 \mu \mathrm{M}$ of thapsigargin abolished calcium waves evoked by

in propagating intercellular calcium waves, octanol and heptanol were used to uncouple gap junctions. As shown in Figure 8, inhibition of gap junctions with $0.6 \mathrm{mM}$ octanol or $1 \mathrm{mM}$ heptanol was associated with a significant reduction in the extent of intercellular calcium wave propagation in enteric glia. In these conditions, a few surrounding cells still responded with an increase in $\left[\mathrm{Ca}^{2+}\right]_{i}$, suggesting the possibility of an alternative pathway. In separate experiments, pretreatment of enteric glia with 0.6 $\mathrm{mM}$ octanol or $1 \mathrm{mM}$ heptanol did not alter the subsequent increment of $\left[\mathrm{Ca}^{2+}\right]_{\mathrm{i}}$ induced by $100 \mu \mathrm{M}$ $\operatorname{ATP}\left(\right.$ mean $\Delta\left[\mathrm{Ca}^{2+}\right]_{\mathrm{i}}=252 \pm 16,253 \pm 16$, and $309 \pm$ $38 \mathrm{nM}$ for control, octanol, and heptanol, respectively), indicating that neither octanol nor heptanol blunts ATP-induced increase of $\left[\mathrm{Ca}^{2+}\right]_{i}$ in cultured enteric glia.
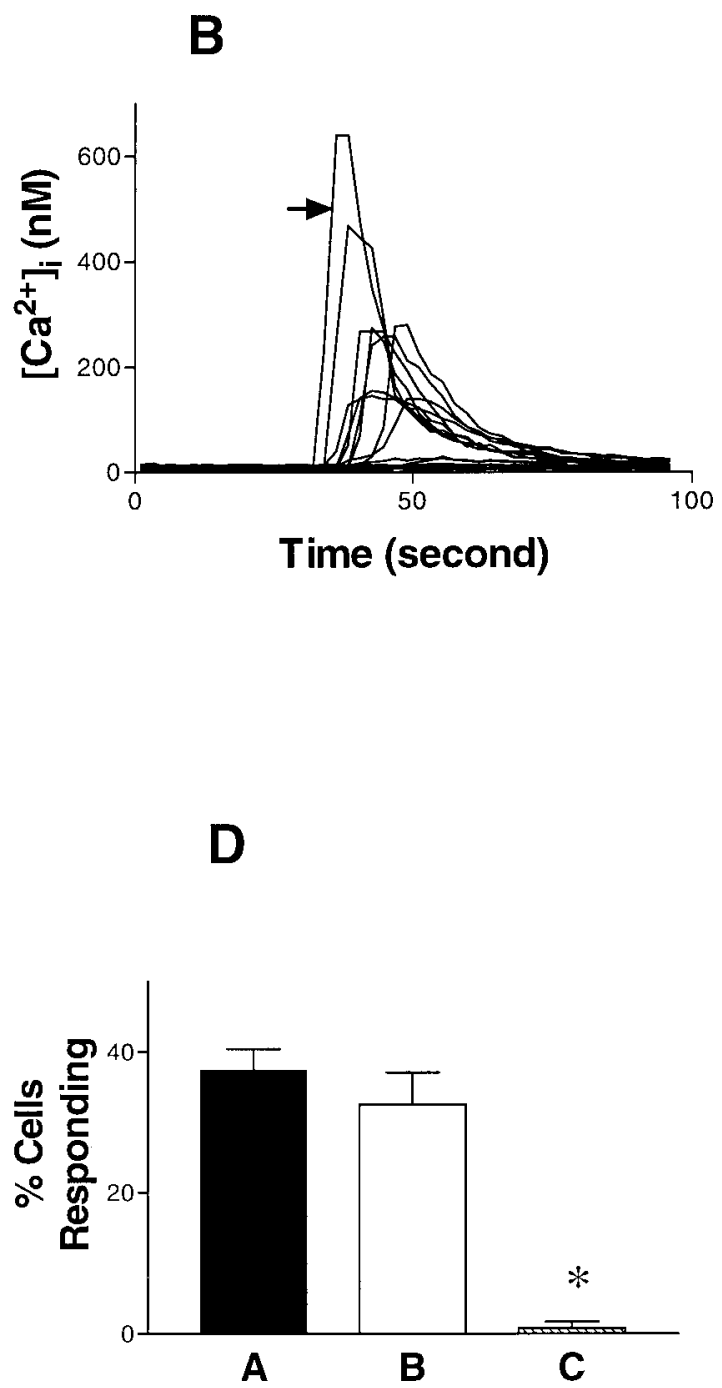

mechanical stimulation. D: Averaged percentage of cells responding under various experimental conditions after mechanical stimulation $(\mathrm{A}=$ control, $\mathrm{n}=13 ; \mathrm{B}=$ removal of extracellular calcium, $\mathrm{n}=5 ; \mathrm{C}=$ pretreatment with thapsigargin, $\mathrm{n}=6$ ). $\mathrm{n}=$ number of experiments. Asterisk, $P<0.01$. Arrows indicate the stimulated cells.

\section{Participation of ATP in Intercellular Calcium Waves}

While gap junctions are involved in intercellular calcium waves in enteric glia, alternate mechanisms may also be involved. Release of ATP into the extracellular space could induce a rise of $\left[\mathrm{Ca}^{2+}\right]_{\mathrm{i}}$ in cultured enteric glia. To demonstrate the involvement of ATP in mechanically stimulated intercellular calcium waves in enteric glia, both ATPase and desensitization of purinergic receptors were used. When apyrase $(8 \mathrm{U} / \mathrm{ml})$ was added to the medium, the extent of intercellular calcium waves initiated by mechanical stimulus was significantly reduced (Fig. 9). The inhibition of intercellular calcium waves in enteric glia was incomplete, even at a high dose of apyrase $(80 \mathrm{U} / \mathrm{ml})$. Pretreatment of enteric glia with $100 \mu \mathrm{M}$ ATP to desensitize purinergic 
A

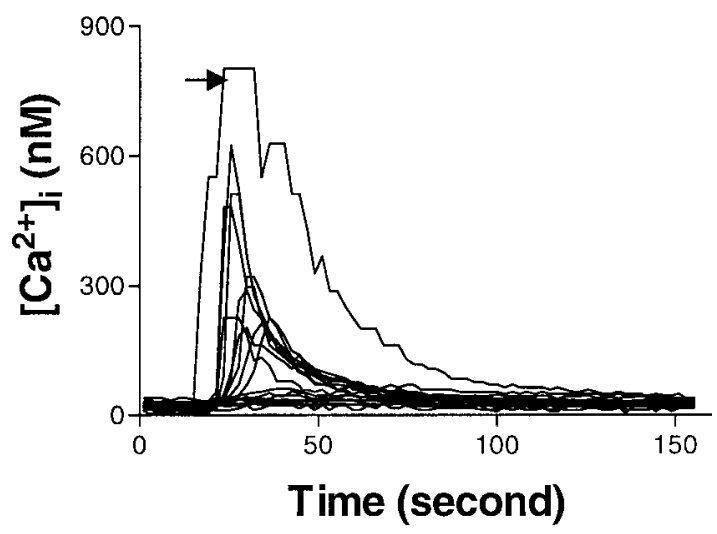

B

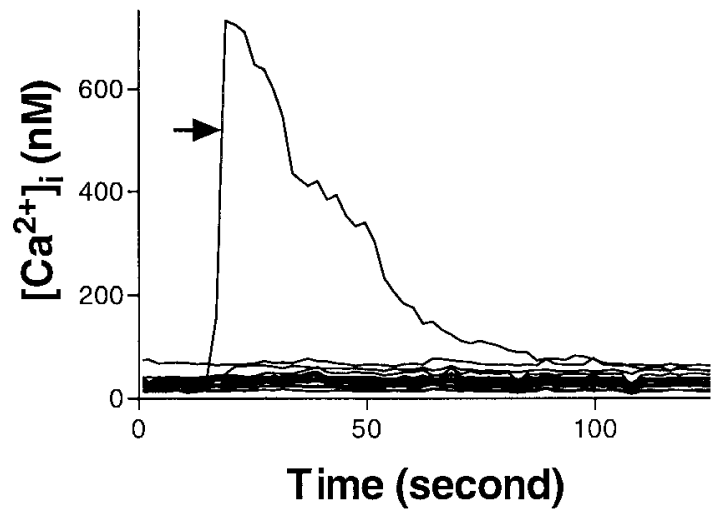

C

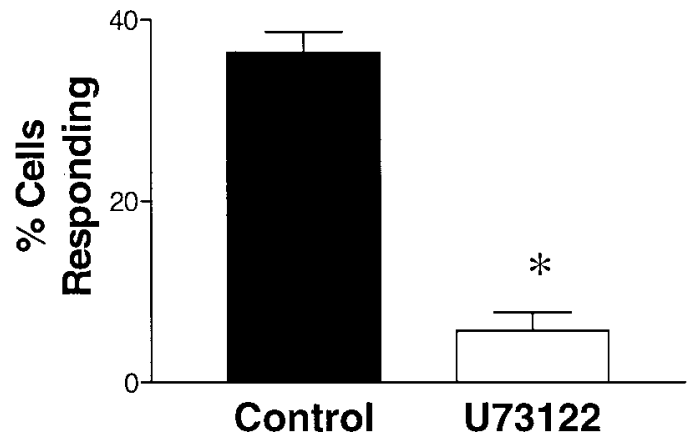

Fig. 5. Pretreatment of enteric glia with $1 \mu \mathrm{M}$ of U73122 significantly inhibited the propagation of calcium waves induced by mechanical stimulation. A: Calcium waves in control cells treated with vehicle $(0.1 \%$ DMSO). B: Calcium waves in U73122-treated cells. C: Averaged cells responding in U73122-treated cells $(n=9)$ decreased significantly as compared to control $(\mathrm{n}=6) . \mathrm{n}=$ number of experiments. Asterisk, $P<0.01$. Arrows indicate the stimulated cells.
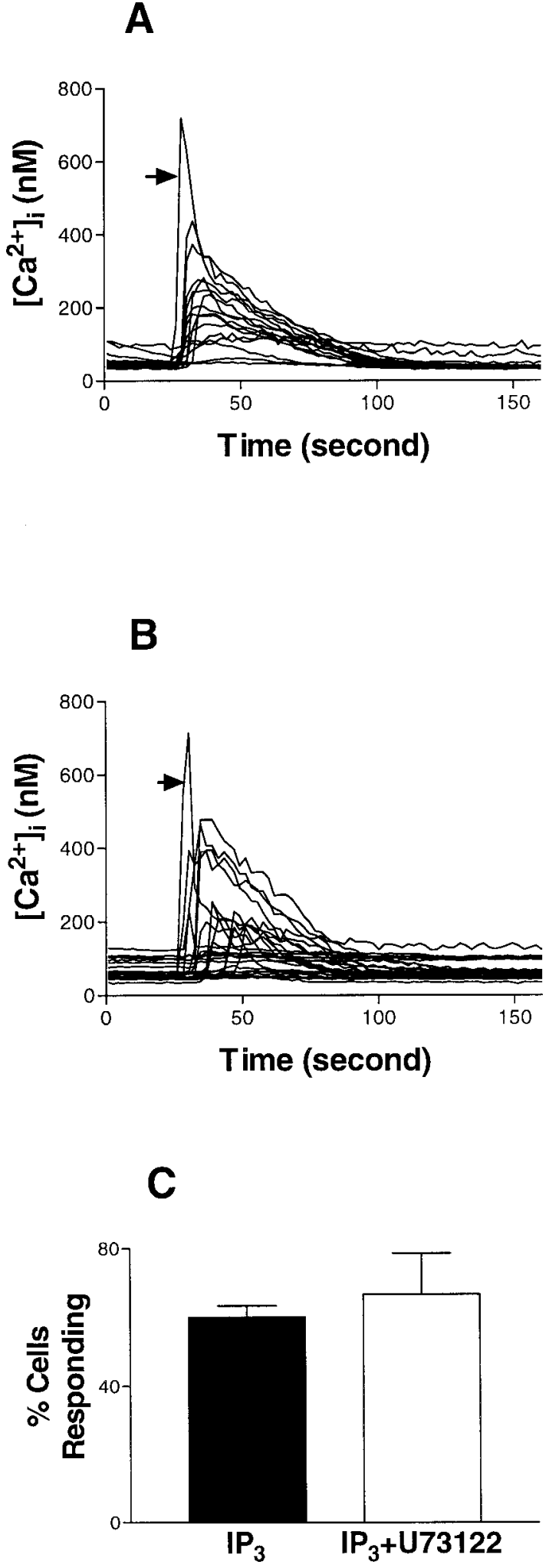

Fig. 6. U73122 did not affect the propagation of calcium waves evoked by microinjection of $\mathrm{IP}_{3}(100 \mu \mathrm{M})$. A: Microinjection of $\mathrm{IP}_{3}$ elicited the propagation of calcium waves in cultured enteric glia $(\mathrm{n}=$ 4). B: Pretreatment of enteric glia with U73122 $(1 \mu \mathrm{M})$ did not demonstrate any effect on calcium waves induced by microinjection of $\mathrm{IP}_{3}$ $(\mathrm{n}=5)$. C: Mean percentages of cells responding in control and U73122-treated cells were not significantly different. $\mathrm{n}=$ number of experiments. Arrows indicate the stimulated cells. 

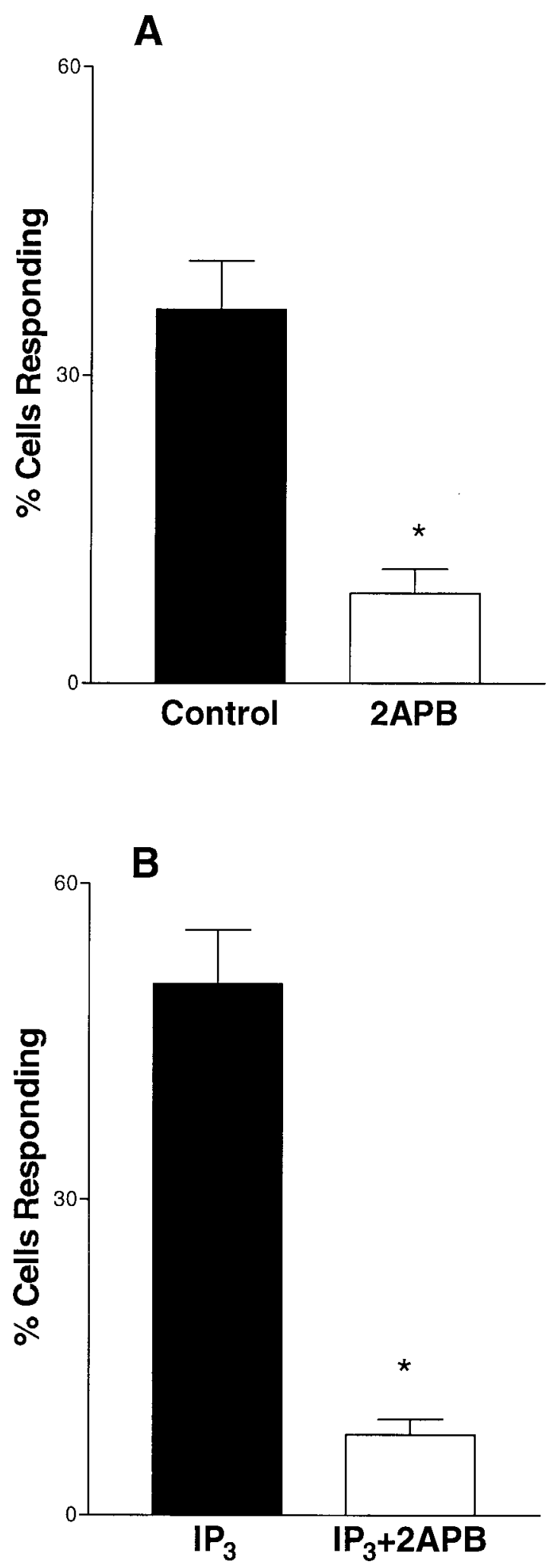

Fig. 7. IP3 receptor antagonism inhibited the calcium waves induced by both mechanical stimulation $(\mathbf{A}, \mathrm{n}=4)$ and microinjection of $100 \mu \mathrm{M} \mathrm{IP}_{3}(\mathbf{B}, \mathrm{n}=3) . \mathrm{n}=$ number of experiments. Asterisk, $P<0.01$. receptors significantly attenuated, but did not abolished, the extent of mechanically induced intercellular calcium waves from $47 \% \pm 10 \%$ to $22 \% \pm 4 \%$ of cells responding $(P<0.05)$.

\section{DISCUSSION}

The present study demonstrates that enteric glial cells are capable of transmitting increases in $\left[\mathrm{Ca}^{2+}\right]_{i}$ from a single cell to surrounding cells. These intercellular calcium waves involve a sequence of intracellular steps in which phospholipase $\mathrm{C}$ and $\mathrm{IP}_{3}$ play critical roles. Furthermore, both diffusion of intracellular messenger via gap junctions and release of extracellular ATP propagate intercellular calcium waves in cultured enteric glia.

Enteric neurons operate in synchrony to evoke coordinated responses of the musculature or secretory epithelium in a segment of gastrointestinal tract. Whether enteric glia form a network and communicate with each other to synchronize their activity is unknown. Gap junctions have been observed between enteric glia by freeze-fracture techniques (Gabella, 1981), and demonstration of dye coupling in enteric glia (Hanani et al., 1989) suggests the existence of low-resistance pathways between glia. The current studies raise the possibility of an enteric glial network with potential functional synchronization.

Similar to astrocytes in the central nervous system, deformation of the membrane of a single enteric glial cell with a mechanical stimulus initiates a $\left[\mathrm{Ca}^{2+}\right]_{\mathrm{i}}$ response which is then communicated to many surrounding cells. In contrast to mechanical stimulation, focal extracellular application of agents such as ATP and endothelin induces a more widespread propagation of intercellular calcium waves in enteric glia, which extended beyond the microscopic field being examined.

A detailed analysis of the mechanism involved in the initiation and propagation of intercellular calcium waves first requires identification of the sources of the calcium transients. Two observations suggest that calcium release from intracellular calcium stores, rather than extracellular calcium influx, is necessary for the initiation and propagation of intercellular calcium waves induced by mechanical stimulation. Intercellular calcium waves were observed in the absence of extracellular calcium, with an extent that was comparable to that observed in the presence of external calcium. Intercellular calcium waves were abolished when internal calcium stores were depleted by thapsigargin. As previously reported, abolition of calcium waves by thapsigargin suggests that a calcium-induced calcium release mechanism does not participate in intercellular calcium waves (Charles et al., 1993). $\mathrm{IP}_{3}$-induced calcium release seems more likely to be involved. Experiments involving the inhibition of PLC activity, the main source of $\mathrm{IP}_{3}$ production, reinforce this conclusion. Moreover, the observation that blockade of $\mathrm{IP}_{3}$ receptors by $2 \mathrm{APB}$ resulted in marked attenuation of intercellular calcium waves demonstrates that the $\mathrm{IP}_{3}$ - 

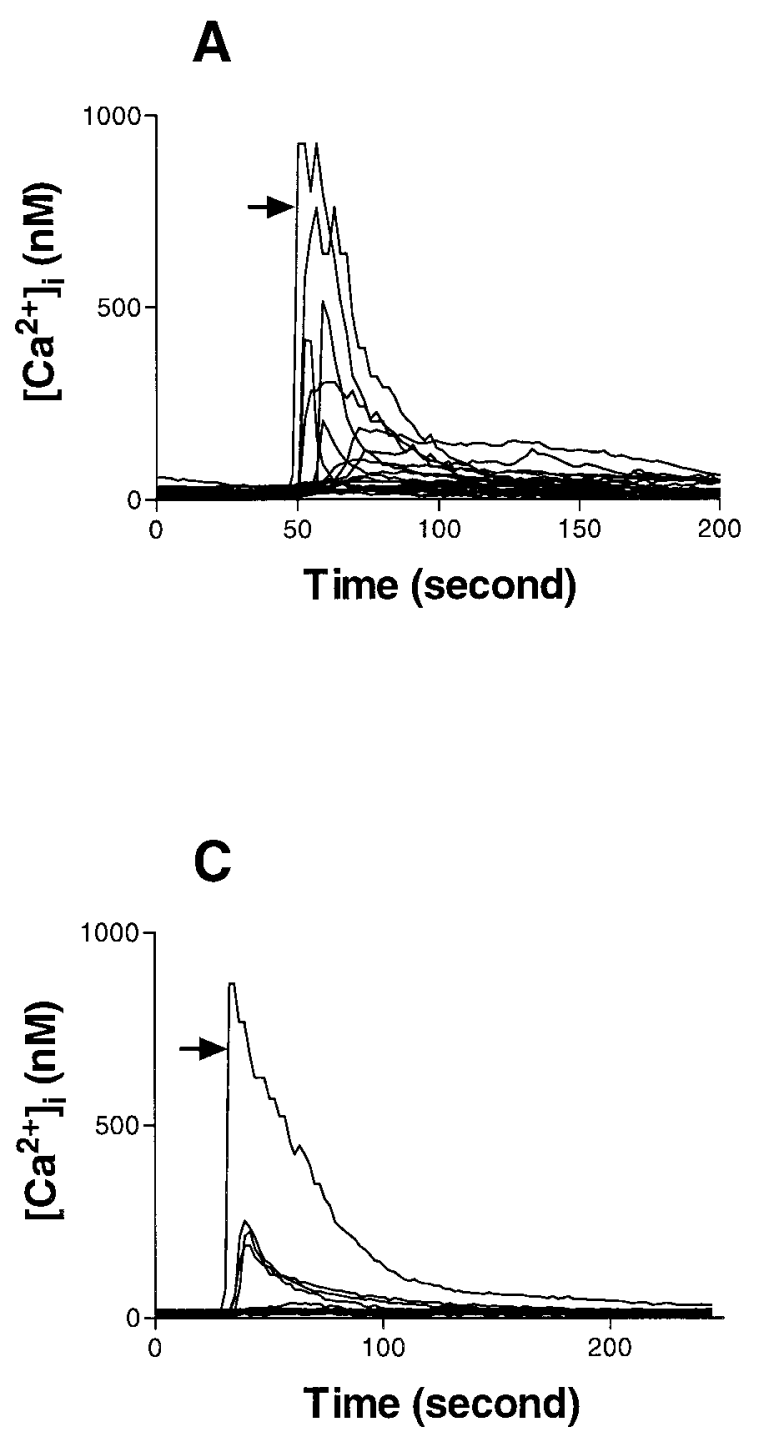

Fig. 8. Uncoupling of gap junctions blocked mechanically stimulated calcium waves. A: Control cells $(\mathrm{n}=6)$. B: Cells treated with 0.6 $\mathrm{mM}$ of octanol $(\mathrm{n}=10)$. C: Cells treated with $1 \mathrm{mM}$ of heptanol $(\mathrm{n}=$

sensitive calcium pool is the predominant source for intercellular calcium waves in enteric glia.

The mechanism that underlies intercellular calcium waves has been studied in cultured cells such as astrocytes (Charles et al., 1993; Venance et al., 1995, 1997), hepatocytes (Hirata et al., 2002), and airway epithelial cells (Boitano et al., 1992). In these cells, mechanical stimulation of one cell leads to the propagation of a calcium wave throughout neighboring cells via gap junctions. Studies by Sanderson et al. (1994) have demonstrated that the major determinant in the propagation of intercellular calcium waves is the diffusion of $\mathrm{IP}_{3}$, produced upon mechanical stimulation, through gap junctions. Although junctional permeability for $\mathrm{IP}_{3}$ has not yet been demonstrated in enteric glia, there are three reasons to believe that the messenger passing through gap junctions in enteric glia is predominantly $\mathrm{IP}_{3}$ rather than calcium. First, the increase of $\left[\mathrm{Ca}^{2+}\right]_{\mathrm{i}}$ in mechanically stimulated cells did not spread to other
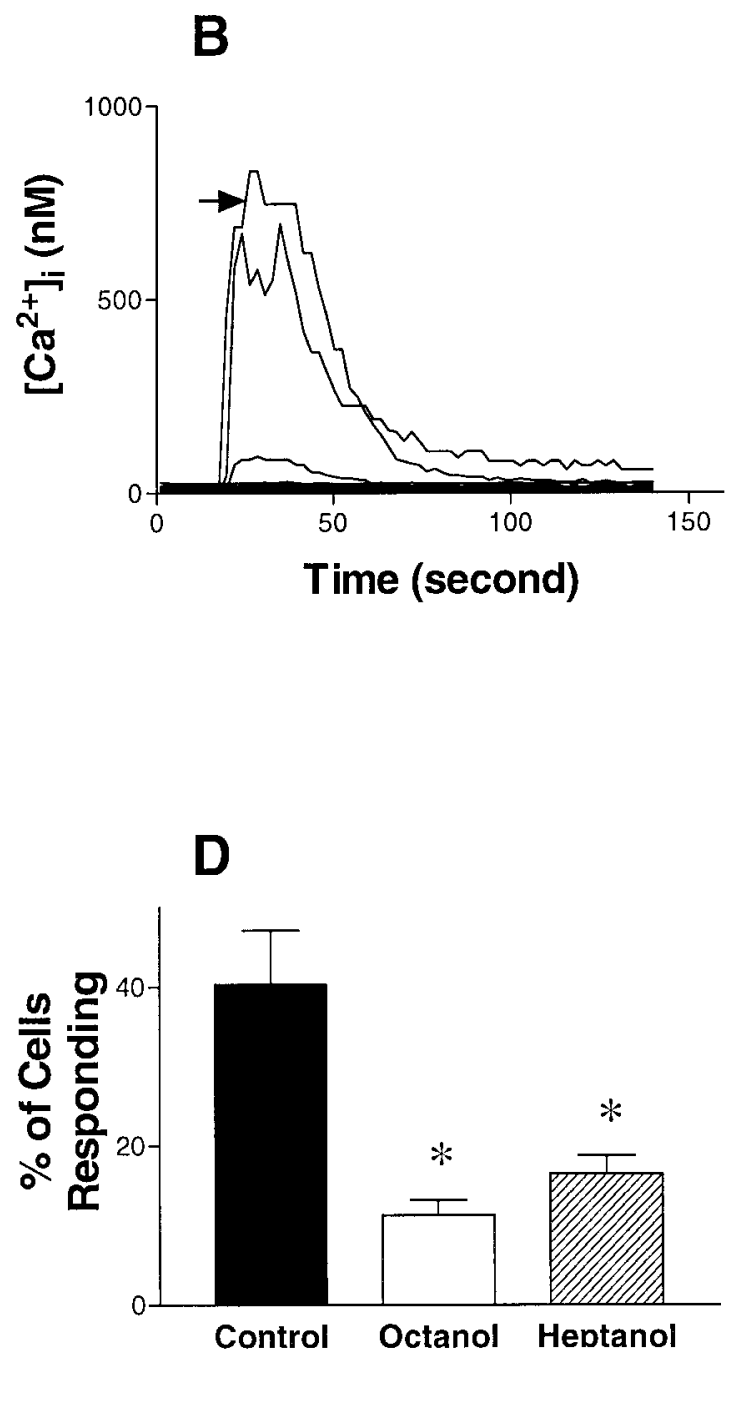

8). D: Averaged percentages of cells responding under various conditions. Asterisk, $P<0.01 . \mathrm{n}=$ number of experiments. Arrows indicate the stimulated cells.

cells in the presence of U73122, indicating that an increase in $\left[\mathrm{Ca}^{2+}\right]_{\mathrm{i}}$ alone was not sufficient for propagation of intercellular calcium waves. Second, bypassing PLC activity by microinjection of $\mathrm{IP}_{3}$ into enteric glia in the presence of U73122 resulted in intercellular calcium waves. Third, elevated $\left[\mathrm{Ca}^{2+}\right]_{\mathrm{i}}$ in stimulated cells was not transmitted to the adjacent cells pretreated with $2 \mathrm{APB}$, which specifically inhibits $\mathrm{IP}_{3}$ receptors. These data are in agreement with studies in astrocytes and airway epithelial cells. The role of $\mathrm{IP}_{3}$ in the propagation process described in enteric glia is in agreement with a general model in nonexcitable cells in which the $\mathrm{IP}_{3}$-sensitive pathway is more important relative to calcium-induced calcium release (Sanderson et al., 1994).

The rate of $\mathrm{IP}_{3}$ diffusion through gap junctions or gap junction permeability has been demonstrated to be critical for intercellular calcium waves in a variety of cell types. In enteric glia, gap junctions were first described 

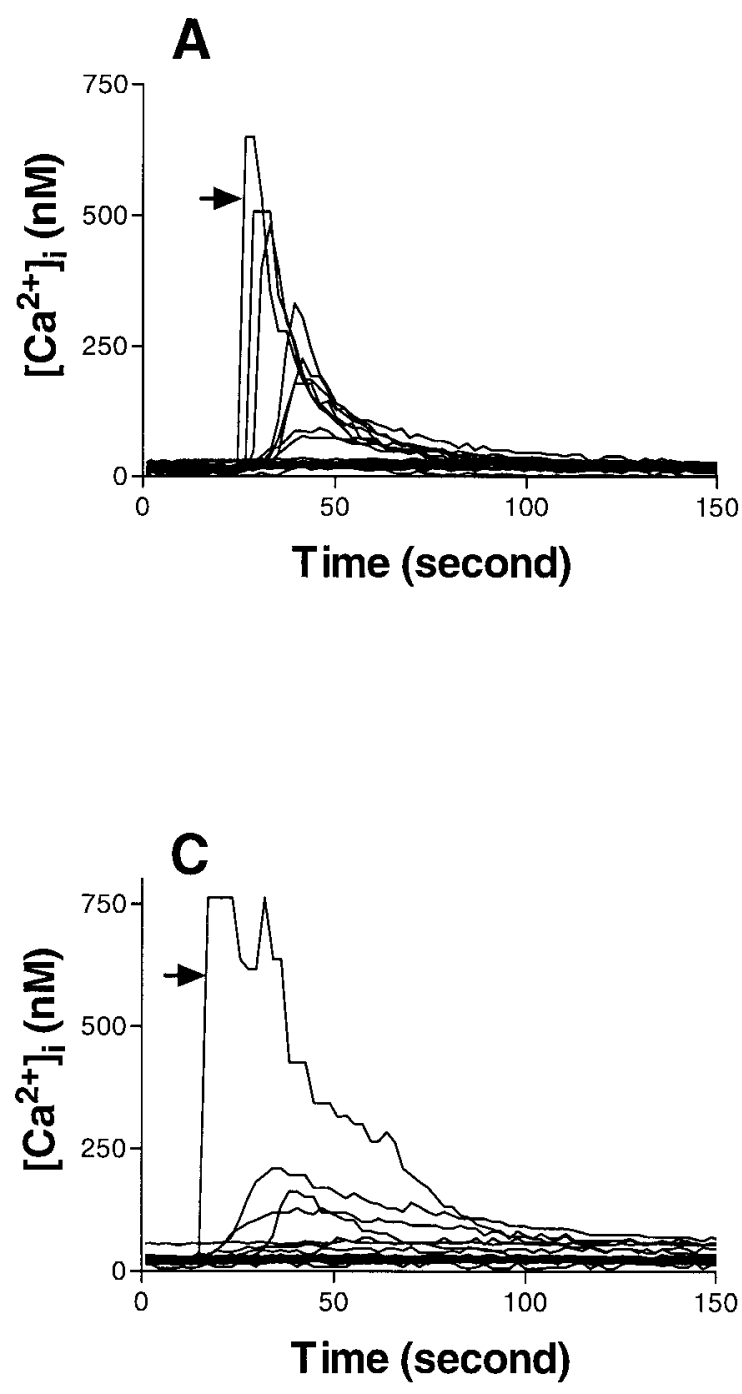

Fig. 9. Degradation of extracellular ATP partially inhibited the calcium waves induced by mechanical stimulation. A: Control cells $(n=11)$. B: Cells treated with $8 \mathrm{U} / \mathrm{ml}$ apyrase $(n=5)$. C: Cells treated

by Gabella (1981) and later confirmed to be dye-coupled (Hanani et al., 1989). In the present study, uncoupling gap junction communication by octanol and heptanol attenuated propagation of intercellular calcium waves in enteric glia, suggesting a requirement for functional gap junctions. Although this conclusion is weakened by the potential of octanol and heptanol to attenuate agonist-mediated increases in $\left[\mathrm{Ca}^{2+}\right]_{\mathrm{i}}$, these results are in agreement with our observation that injection of $\mathrm{IP}_{3}$ into one cell of cultured glia can initiate an increase in $\left[\mathrm{Ca}^{2+}\right]_{\mathrm{i}}$ not only in that cell but also in adjacent neighbors. Furthermore, neither octanol nor heptanol alters the ATP-induced increment of $\left[\mathrm{Ca}^{2+}\right]_{i}$ in cultured enteric glia.

Alternative mechanisms such as the release of ATP into the extracellular space have also been reported to participate in intercellular calcium waves (Guthrie et al., 1999; Newman, 2001). ATP and glutamate are known to be released by astrocytes and act as agonists to increase $\left[\mathrm{Ca}^{2+}\right]_{\mathrm{i}}$ in several cell types. Whether en-
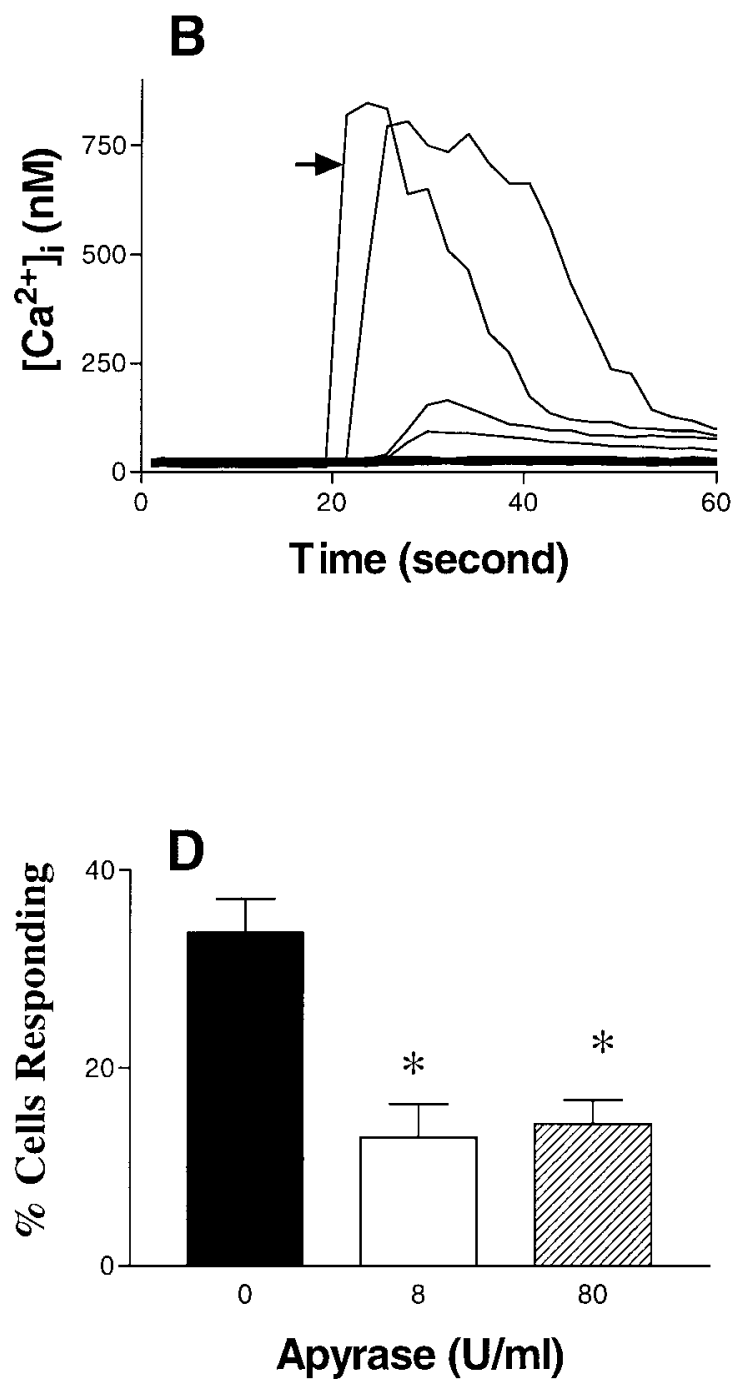

with $80 \mathrm{U} / \mathrm{ml}$ apyrase $(\mathrm{n}=9)$. D: Averaged percentages of cells responding under different conditions. $\mathrm{n}=$ number of experiments. Asterisk, $P<0.05$. Arrows indicate the cells stimulated.

teric glia are capable of releasing ATP has not been reported; however, the $\mathrm{P}_{2 \mathrm{U}}$ subtype purinergic receptor has been demonstrated on enteric glia (Kimball and Mulholland, 1996). Both enzymatic degradation of ATP and desensitization of purinergic receptors by extracellular ATP inhibited the propagation of intercellular calcium waves in the present study, suggesting that release of extracellular ATP may participate in the propagation of intercellular calcium waves in cultured enteric glia.

The identification of multiple pathways involved in intercellular calcium waves in enteric glia suggests that initiation or propagation could be regulated at different levels. Regulation may include activation of $\mathrm{PLC}$, filling or depletion of $\mathrm{IP}_{3}$-sensitive internal calcium stores, regulation of $\mathrm{IP}_{3}$ receptors, and permeability of gap junctions and release of ATP. This diversity in regulation sites could permit selectivity in the triggering and the patterning of intercellular calcium waves in enteric glia. The physiological significance of 
these events in the enteric nervous network will require further investigation.

In summary, this study demonstrates for the first time that enteric glial cells are capable of transmitting increases in $\left[\mathrm{Ca}^{2+}\right]_{\mathrm{i}}$ from a single cell to surrounding cells. Intercellular calcium waves occur through diffusion of intracellular messenger via gap junctions, a process involving phospholipase $\mathrm{C}$ and $\mathrm{IP}_{3}$. Extracellular ATP may also mediate the intercellular communication in cultured enteric glia.

\section{REFERENCES}

Boitano S, Dirksen ER, Sanderson MJ. 1992. Intercellular propagation of calcium waves mediated by inositol trisphosphate. Science 258:292-295.

Charles AC, Dirksen ER, Merrill JE, Sanderson MJ. 1993. Mechanisms of intercellular calcium signaling in glial cells studied with dantrolene and thapsigargin. Glia 7:134-145.

Churchill GC, Louis CF. 1998. Roles of $\mathrm{Ca}^{2+}$, inositol trisphosphate and cyclic ADP-ribose in mediating intercellular $\mathrm{Ca}^{2+}$ signaling in sheep lens cells. J Cell Sci 111:1217-1225.

Gabella G. 1981. Ultrastructure of the nerve plexuses of the mammalian intestine: the enteric glial cells. Neuroscience 6:425-436.

Guthrie PB, Knappenberger J, Segal M, Bennett MVL, Charles AC, Kater SB. 1999. ATP released from astrocytes mediates glial calcium waves. J Neurosci 19:520-528.
Hanani M, Zamir O, Baluk P. 1989. Glial cells in the guinea pig myenteric plexus are dye coupled. Brain Res 497:245-249.

Hirata K, Pusl T, O'Neill AF Dranoff JA, Nathanson MH. 2002. The type II inositol 1,4,5-trisphosphate receptor can trigger $\mathrm{Ca}^{2+}$ waves in rat hepatocytes. Gastroenterology 122:1088-1100.

Kimball BC, Mulholland MW. 1996. Enteric glia exhibit $\mathrm{P}_{2 \mathrm{U}}$ receptors that increase cytosolic calcium by a phospholipase C-dependent mechanism. J Neurochem 66:604-612.

Ma HT, Patterson RL, van Rossum DB, Birnhaumer L, Mikoshiba K, Gill DL. 2000. Requirement of the inositol trisphosphate receptor for activation of store-operated $\mathrm{Ca}^{2+}$ channels. Science 287:16471651.

Newman EA. 2001. Propagation of intercellular calcium waves in retinal astrocytes and Muller cells. J Neurosci 21:2215-2223.

Sanderson MJ, Charles AC, Boitano S, Dirksen ER. 1994. Mechanisms and function of intercellular calcium signaling. Mol Cell Endocrinol 98:173-187.

Scemes E, Suadicani SO, Spray DC. 2000. Intercellular communication in spinal cord astrocytes: fine tuning between gap junctions and $\mathrm{P}_{2}$ nucleotide receptors in calcium wave propagation. $J$ Neurosci 20:1435-1445.

Venance L, Piomelli D, Glowinski J, Giaume C. 1995. Inhibition by anandamide of gap junctions and intercellular calcium signaling in striatal astrocytes. Nature 376:590-593.

Venance L, Stella N, Glowinski J, Giaume C. 1997. Mechanism involved in initiation and propagation of receptor-induced intercellular calcium signaling in cultured rat astrocytes. J Neurosci 17: 1981-1992.

Yule DI, Stuenkel E, Williams JA. 1996. Intercellular calcium waves in rat pancreatic acini: mechanism of transmission. Am J Physiol 271:C1285-C1294.

Zhang W, Sarosi G Jr, Barnhart D, Yule DI, Mulholland MW. 1997. Endothelin-activated calcium signaling in enteric glia derived from neonatal guinea pig. Am J Physiol 272:G1175-G1185. 